\title{
OPINION OF ICT COORDINATORS ON THE INCIDENCE OF TELEMATIC TOOLS
}

\author{
Beatriz Berrios-Aguayo $^{1}$ (D), María Dolores Molina-Jaén ${ }^{2}$ (D), Antonio Pantoja-Vallejo ${ }^{1 *}$ (D) \\ ${ }^{1}$ Universidad de Jaén (Spain) \\ ${ }^{2}$ Centro universitario SAFA, Úbeda (Spain) \\ bberrios@ujaen.es,mdmolina@fundacionsafa.es, *Correspondingauthor: apantoja@ujaen.es
}

Received February 2019

Accepted October 2019

\begin{abstract}
The objective of this study was to evaluate the role of information and communication technologies (ICT) in the learning of primary school students, as assessed by ICT coordinators of the schools in Andalusia (a network already considered by the Spanish Educational Administration as ICT centres). For this, a total of 34 ICT coordinators from various primary education centres in Andalusia participated. With the objective of knowing the scope of the policies that are carried out, as well as determining the true incidence of ICT in the classroom - not only as a tool, but also as a way of teaching - a questionnaire was created and validated for the coordinators TIC. The results indicated that (a) the use by ICT teachers in the classroom is still reduced and (b) the lack of training received by teachers, as well as scarce technological resources, are the main barriers to attaining a higher use of ICT in the didactic process. The findings suggest that integral and transversal insertion of ICTs in the classroom should be priority objectives in deriving optimal curricular development in for primary school students.
\end{abstract}

Keywords - Coordinators, ICT, Teaching methods, Primary education.

\section{To cite this article:}

Berrios-Aguayo, B., Molina-Jaén, M.D., \& Pantoja-Vallejo, A. (2020). Opinion of ICT coordinators on the incidence of telematic tools. Journal of Technology and Science Education, 10(1), 142-158.

https://doi.org/10.3926/jotse.690

\section{Introduction}

Students of today have changed their interests with respect to school, in addition to their means of acquiring knowledge. Information they receive now is more immediate, more global, and more comprehensive. Christensen, Horny and Johnson (2011), for instance, suggest the way students learn is changing. In particular, they note, learning is more "disruptive" in that it is acquired through technology, use of the Internet, e-learning, and/or m-learning. This occurs because the students have at their disposal the means to access information (and thereby of acquire knowledge) from anywhere and at any time (Bringué, Sadaba \& Tolsa, 2011; Reig, 2012). For this reason, the role of the teacher has changed substantially. 
This change in the teacher's role has many implications, chief among which is the need to remain abreast of advances in information and communication technologies (ICT). The role of the ICT coordinator has also gained more prominence within the educational context. In Andalusia, such changes were realised with the Andared Plan (2003) - an initiative that reflected a firm commitment to the use of ICT in education in general and boosting its use in individual schools. Subsequently, in 2009 the ICT School 2.0 Project appears. In implementing these plans, ICT coordinators face the tasks of advising, revitalising, coordinating, and administrating. This includes:

- Advice to other teachers on available ICT tools, news, and existing updates as well as best practises regarding the use of ICT within school contexts;

- Dynamisation in the use of ICT in the classroom and with teachers, thereby promoting communication within the educational environment;

- Coordination of ICT plans in the centre, resolution of incidents/conflicts, and teacher training;

- Administration and control of technological procedures carried out.

Given these responsibilities, ICT coordinators generally are the people with the greatest knowledge and understanding of digital tools used in the school context. Therefore, the opinion of the coordinators on how the educational centres of a given community make use of these tools is fundamental for a better development of digital competence in that territory. Despite this, there are few studies focusing on the coordination and incorporation of ICT in schools as the main research problem. Therefore, this research endeavours to define areas where there remains a lack of knowledge about ICT in the classroom. Such factors can limit the fluid and real-time use of technology for learning. Such an examination could benefit from delineating and reflecting on the opinion of the ICT coordinators at the Andalusian educational centres.

Based on the above, this study aims to solicit the opinions of the ICT coordinators of primary education centres of the autonomous community of Andalusia with respect to the contribution of ICT-based tools in the evolution of its teaching framework. A secondary goal was to analyse the level of homogeneity or heterogeneity of these opinions. These objectives can be further divided into two:

a) Know and evaluate whether teachers frequently use ICT in their teaching activity, how they insert them into their methodology, and what benefits these elements are perceived to produce in student learning;

b) Determine the barriers that prevent further development of ICT within the didactic process.

\section{Literature Review}

Information and communication technologies (ICT) are ubiquitous in society and should also be in the classroom. Bringué-Sala and Sadaba-Chalezquer (2009) state that, unlike companies, schools have not achieved a comprehensive use of ICT tools. In the case of households, although ICTs have appeared, these tools are primarily used with a clear inclination for leisure, communication, and informal learning, as evidenced by numerous studies (Area, 2005; Barroso-Osuna \& Cabero-Almenara, 2013; Bringué et al., 2011; Cabero-Almenara \& Alonso-García, 2007a,b; Donnelly, McGarr \& O’Reilly, 2011; Formichella, 2018; Hernández, Cumpa \& Rodríguez. 2018; Macià Bordalba, 2016; Suárez-Rodríguez, Almeric, Orellana \& Díaz-García, 2018; Sutherland, Armstrong, Barnes, Brawn, Breeze, Gall et al., 2004; Tondeur, van Keer, van Braak \& Valcke, 2008).

Some teachers perceive ICT as threatening (Wellington, 2001; Wishart, 2004) since it can change what they define and understand as teaching (i.e. representing unknown didactics and methodologies). They may rather rely on the textbook - although this teaching tool, in and of itself, does not guarantee learning. By the same token, technology, interpreted as a tool within a traditional educational model, also does not ensure any improvement in learning; also essential is training the more traditional teacher who is losing motivation and effectiveness. This lack was reflected in the Pisa Report (2009), itself based on scandalous 
figures with respect to the percentage of school dropouts or lack of school success (Díaz-Sotero, 2012) and more recent reports (e.g. Vera, 2016) as well. In the Pisa Report (2018), the persistent lack of a complete development of digital competence in classrooms by teachers and students is highlighted. It is a fact that the unlimited information that reaches both groups is often associated with insufficient media literacy. One result of this unfamiliarity is being easily deceived with false data or, alternatively failing to acquire adequate knowledge or information.

Current academic curricula demand more than proficiency in ICT (Monje-Fernández, 2012). An ICT-based nomenclature can be used if traditional education is understood as 1.0, the use of participatory networks such as web 2.0 and the combination of both as 3.0 (using other people's web material). Therefore, the concept of teaching 4.0 is necessary (Fernández-Coca, 2012; Ngoc-Thanh, 2019) both if the material is generated using traditional means and if ICT is used for specific needs in the classroom. Therefore, technology is not an isolated element but rather a potential tool for change as educational needs move forward and evolve. Adell and Castañeda (2012) define it as the basis of a deeper turn, a change they call "changing towards emerging pedagogies".

This change of nomenclature makes the content increase exponentially on the Internet (Prestridge, 2012), favoring leisure and relationships, causing changes in the brain, in the way it is learned and in the resources used to memorise content before fulfilling other functions (such as seeking information, organising and transforming it). Memory yes, but not storage but procedure. The Internet becomes an ally of transactional memory (Sparrow, Liu \& Wegner, 2011) increasing multitasking capacity as more and more things tend to be done at the same time. In this way, modified learning is seen exponentially. In these changes, the most important thing is not retention, but the ability to filter information. This excessive information, as is available on the Internet, often causes technology addiction to occur, registering problems of "craving" (withdrawal syndrome) due to the stimulation received (Carr, 2017). What may be thought of as ICT addiction activates the same circuits as substance addictions, which is why in extreme cases the corrective measures are the same as in other addictions. The more the Internet is used, the more the brain is activated. Small (2010) showed that after 5 hours of using the resource, the brains of the participants in their studies showed changes in neuronal circuits. Creativity problems also appear. Some experts think that creativity needs memory, that when ideas are needed, knowledge stored in memory is used and can be less effective if content is are stored online. Weakness is compensated by the large amount of resources that only favour the opposite. since creativity arises from knowledge (Ramos-Moreno, López-Fernández \& Llamas-Salguero, 2017). That is why learning is modified depending on the use made of ICTs both outside and inside the classroom. Indeed, it is here that the coordinator enters the game, trying to control the use made of computer tools and facilitating the means by which students know how to ideally access those resources.

That said, it is worth highlighting the primary importance of the role of ICT coordinators in the new digital classroom (Sosa-Díaz \& Valverde-Berrocoso, 2017). It is necessary for teachers to explore pedagogical strategies that, with the use of ICT, improve traditional learning (Peláez \& Osorio, 2015). The coordinators assume a dynamic role within the technological practice that is necessary to know (González-Pérez, 2017), being the centres that have the most digitally competent ICT coordinators (Fernández-Cruz, Fernández-Díaz \& Rodríguez-Mantilla, 2018). Educational policies in this sense (de Pablos-Pons, Bravo \& Moreno, 2010) respond to a need for training which, in some regions such as the Canary Islands or Extremadura, have been better received in that teachers are more involved in innovation than in other communities (Díaz, García, and Muriel, 2010).

\section{Methodology \\ 3.1. Design}

A descriptive-exploratory approach (Cantón Mayo, Valle-Flórez \& Arias-Gago, 2008) was followed in order to delineate and interpret the role of ICT coordinators in Andalusian centres (as a means of helping both decision-making and future actions vis a vis educational programming). The choice of this type of studies appropriate in that enables predicting and identifying the relationships that exist between two or 
more variables (Best, 1972; Bisquerra-Alzina, 1989; Fox, 1981) and, as well, explaining the reality being studied.

\subsection{Participants}

The selected sample is drawn from the ICT coordinators of various centres in Andalusia, Spain; in total, 34 coordinators, spread across the eight provinces of the region, participated. The participants were recruited at the IX EABE Educational Meeting, held on 31 March and 1 April, 2017 in Almería. Of these, $28(82.3 \%)$ were men and $6(17.6 \%)$ were women. All had been coordinators for more than 4 years and had received specific training for their position. The main elements of that training are:

- Collaborate with teachers in the design and/or adaptation of ICT resources integrated into the curriculum;

- Promote, in the teachers, a positive attitude toward ICTs and, as well, generate strategies for its further development;

- Promote systematic innovation in terms of ICT material;

- Together with the teaching staff, identify areas of the curriculum in which ICT could readily be integrated;

- Determine which ICT resources work most effectively in classrooms.

\subsection{Procedure}

The applied research began with the development of a scale, the main objective of which was to determine the real impact of ICT on student learning, particularly after a decade-long implementation of the Autonomous Community of Andalusia. The ICT coordinators of primary education centres and participating in the IX EABE Educational Meeting were contacted, answering the scale previously created for this purpose (see below). The coordinators completed the questionnaire during the Congress.

\subsection{Description and Validation of the Data Collection Instrument}

After reviewing the specific bibliography on the subject under study, a Likert scale was developed with four response options, to eliminate the phenomenon of centrality observed in studies, as described by Aigneren (2005). The study continued through the following phases: reference to the objectives defined in the research, selection of dimensions, selection of indicators, final formulation of items for each indicator, ordering of the items in each dimension, determination of instrument reliability, and final elaboration. The final instrument went from 116 items in the first proposal to 58; these were subjected to tests of content validity, construct validity, and reliability (see Tables 2-6).

Items on the instrument were divided into five dimensions, as set forth below. These served as objects of study of the current research:

- Modification of student learning through ICT;

- Use of ICT by teachers from a general perspective;

- Incidence of ICT in the classroom;

- Organisational strategies for the application of ICT;

- Barriers to using ICT in the classroom;

The descriptive variables included in the study were years on the job, sex, seniority as a teacher, years as ICT coordinator, and ICT training.

Regarding content validity, this was determined prior to administration of the scale; this involved consulting 12 experts who were asked to evaluate two aspects of each element:

- Relevance of the question posed to achieving the scale's intended results; 
- Clarity of the language used and terminological precision, based on the selected sample;

Those questions whose score on these two points (i.e. relevance of the question and clarity of the language) failed to reach an average of at least 3 points out of a possible 5 were rejected (cf Mendoza $\&$ Garza, 2017).

Next, the factor analysis is addressed. Bartlett's sphericity gave a result of $p \leq .05$, rejecting the null hypothesis at 5\% significance. The magnitudes of the correlation coefficients yielded an index of 0.77 . From the total variance explained, the first five factors were selected, corresponding to $57.76 \%$ (distributed across the five factors).

The factor analysis of rotated components allowed verification that the value of selected items all had the same features and, as well, had positive correlations with other items included within that given factor. The results supported the five factors, which were the final dimensions of the questionnaire (Table 1):

\begin{tabular}{|c|c|}
\hline \multicolumn{2}{|c|}{ First Factor } \\
\hline $28,29,30,31,32,33$ and 44 & Item $29=0,601 \leq 0,829$, item $n^{\circ} 44$ \\
\hline \multicolumn{2}{|c|}{ Second Factor } \\
\hline $\begin{array}{c}48,49,50,51,52,53,54,55,56,57,58 \\
59,60 \text { and } 61\end{array}$ & Item $50=0,607 \leq 0,829$, item $n^{\circ} 11$ \\
\hline \multicolumn{2}{|c|}{$\begin{array}{l}\text { Third Factor } \\
\end{array}$} \\
\hline $\begin{array}{c}77,78,79,80,81,82,83,84,85,86,87 \\
88,89,90 \text { and } 91\end{array}$ & Item $86=0,616 \leq 0,806$, item no 91 \\
\hline \multicolumn{2}{|c|}{ Fourth Factor } \\
\hline $95,96,97,98,99,100,101,102$ and 103 & Item $96=0,639 \leq 0,789$, item $\mathrm{n}^{\circ} 102$ \\
\hline \multicolumn{2}{|c|}{ Fifht Factor } \\
\hline $\begin{array}{l}104,105,106,107,108,109,110,111 \\
112,113,114,115 \text { and } 116\end{array}$ & Item $105=0,643 \leq 0,764$, item $\mathrm{n}^{\circ} 111$ \\
\hline
\end{tabular}

Table 1. Factors that define the dimensions

Reliability was also calculated using Cronbach's alpha for the entire instrument, obtaining an $\alpha=0.93$, which guarantees the unidimensionality of the scale, that is, it measures a single characteristic.

In the same manner, and to provide more precision and rigor to the investigation, the statistical program SPSS 21 was used. This enabled deriving of the asymmetry, kurtosis, and graph of the normality curve. The data obtained from the statistical analysis showed that approximately $90 \%$ of the questionnaire values had an asymmetry coefficient of \pm 0.5 . The kurtosis coefficient indicated that the data is normally distributed, being a curve consistent with the normal distribution graph (Pérez-Juste, 2009).

From the analyses performed, it can be concluded that the instrument meets the reliability requirements necessary for this type of testing.

\section{Results}

In the next section, the main results of the study are analysed, taking as reference the five dimensions that have been identified in the grouping of the items of the scale.

\subsection{Modification of Student Learning Through ICT}

One of the objectives of our study was to verify whether the coordinators appreciated the change taking place in students' learning with the use/availability of ICT, as seen in Section 2, Literature Review. As shown in Table 2, your answers are on that line; Coordinators mostly think that ICTs increase attention, content and procedures are better and deeper as motivation and autonomy grow. In terms of memory, they do not believe that ICTs modify it. 


\begin{tabular}{|c|c|c|c|c|c|}
\hline Item & \multicolumn{2}{|c|}{ Frequency } & Mean $(M)$ & $\begin{array}{c}\text { Standard } \\
\text { deviation }(S D)\end{array}$ & $\begin{array}{l}\text { Maximum and } \\
\text { minimum }\end{array}$ \\
\hline \multirow{4}{*}{$\begin{array}{l}\text { Improving the student's memory } \\
\text { capacity (V1) }\end{array}$} & VF & 10 & \multirow{4}{*}{2.18} & \multirow{4}{*}{0.93} & \multirow{4}{*}{$\begin{array}{l}\text { Max:4 } \\
\text { Min:1 }\end{array}$} \\
\hline & $\mathrm{F}$ & 10 & & & \\
\hline & Q & 12 & & & \\
\hline & $\mathrm{VM}$ & 2 & & & \\
\hline \multirow{4}{*}{ Stimulating student's attention (V2) } & $\mathrm{VF}$ & 0 & \multirow{4}{*}{3.18} & \multirow{4}{*}{0.52} & \multirow{4}{*}{$\begin{array}{l}\text { Max:4 } \\
\text { Min:2 }\end{array}$} \\
\hline & $\mathrm{F}$ & 2 & & & \\
\hline & Q & 24 & & & \\
\hline & VM & 8 & & & \\
\hline \multirow{4}{*}{$\begin{array}{l}\text { Improving quality of learning in } \\
\text { relation to content (V3) }\end{array}$} & VF & 0 & \multirow{4}{*}{3.18} & \multirow{4}{*}{0.62} & \multirow{4}{*}{$\begin{array}{l}\text { Max:4 } \\
\text { Min:2 }\end{array}$} \\
\hline & $\mathrm{F}$ & 4 & & & \\
\hline & Q & 20 & & & \\
\hline & VM & 10 & & & \\
\hline \multirow{4}{*}{ Development procedures (V4) } & $\mathrm{VF}$ & 0 & \multirow{4}{*}{3.29} & \multirow{4}{*}{0.46} & \multirow{4}{*}{$\begin{array}{l}\text { Max:4 } \\
\text { Min:3 }\end{array}$} \\
\hline & $\mathrm{F}$ & 0 & & & \\
\hline & Q & 24 & & & \\
\hline & VM & 10 & & & \\
\hline \multirow{4}{*}{$\begin{array}{l}\text { Increasing motivation in learning } \\
\text { processes (V5) }\end{array}$} & VF & 0 & \multirow{4}{*}{3.47} & \multirow{4}{*}{0.50} & \multirow{4}{*}{$\begin{array}{l}\text { Max:4 } \\
\text { Min:3 }\end{array}$} \\
\hline & $\mathrm{F}$ & 0 & & & \\
\hline & $\mathrm{Q}$ & 18 & & & \\
\hline & $\mathrm{VM}$ & 16 & & & \\
\hline \multirow{4}{*}{$\begin{array}{l}\text { Improving student autonomy in } \\
\text { learning processes (V6) }\end{array}$} & VF & 0 & \multirow{4}{*}{3.47} & \multirow{4}{*}{0.50} & \multirow{4}{*}{$\begin{array}{l}\text { Max:4 } \\
\text { Min:3 }\end{array}$} \\
\hline & $\mathrm{F}$ & 0 & & & \\
\hline & $\mathrm{Q}$ & 18 & & & \\
\hline & VM & 16 & & & \\
\hline \multirow{4}{*}{$\begin{array}{l}\text { Enabling student to obtain more } \\
\text { information so as to have a more } \\
\text { consistent and deeper learning } \\
\text { experience (V7) }\end{array}$} & $\mathrm{VF}$ & 0 & \multirow{4}{*}{3.47} & \multirow{4}{*}{0.61} & \multirow{4}{*}{$\begin{array}{l}\text { Max:4 } \\
\text { Min:2 }\end{array}$} \\
\hline & $\mathrm{F}$ & 2 & & & \\
\hline & $\mathrm{Q}$ & 14 & & & \\
\hline & $\mathrm{VM}$ & 18 & & & \\
\hline
\end{tabular}

Note. Very few (VF), Few (F), Quite (Q), Very much (VM)

Table 2. Values of the Dimensions Linked to Student Learning

As can be seen in Figure 1, the averages are very high: most range between 3 and 3.5. This indicates that, from the standpoint of the coordinators, ICTs modify the learning of the students. The respondents specified this by saying that, in their view, this type of learning is more consistent and profound as well as motivating, autonomous, and quality-based in a categorical way with their assessments.

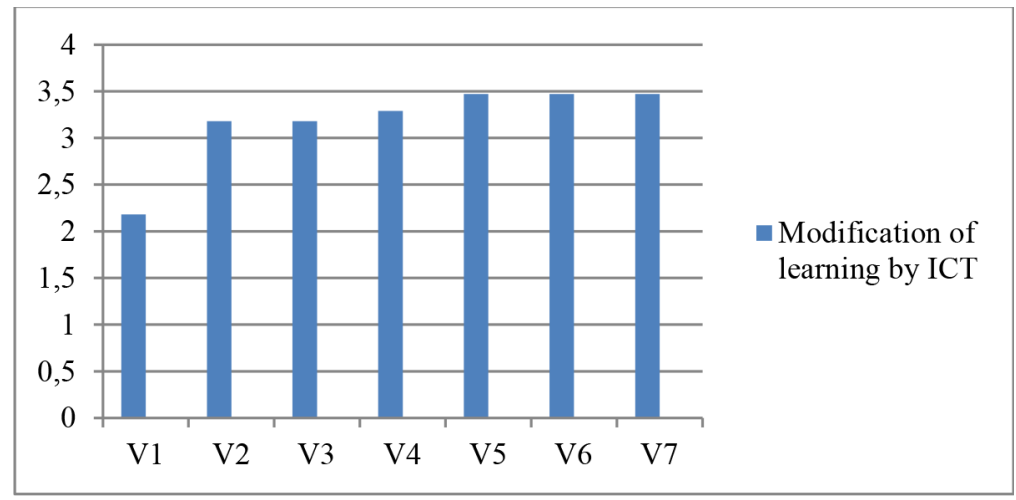

Figura 1. Means comparison 


\subsection{Use of ICT by Teachers from a General Perspective}

Table 3 shows that the coordinators confirmed that teachers use ICT as support for their subject matter, especially to supplement it and deepen students' understanding of the material. Content derived through ICTs is also used to support textbooks, but not to create tools such as wikis, blogs, videos, etc. Nor is the use of ICTs generalised as support for the continuous training of teachers. They are not used in the field of evaluation, nor for the relationship with the family. Very poor values were found throughout the five dimensions, since the general average did not exceed 2.5 and these values are backed by the value of fashion that fluctuates around 2. This valuation only rose in relation to the item suggesting that ICT supports textbooks on the teacher's subject matter.

\begin{tabular}{|c|c|c|c|c|c|}
\hline Ítem & \multicolumn{2}{|c|}{ Frequences } & Means $(M)$ & $\begin{array}{c}\text { Standard } \\
\text { deviation }(S D)\end{array}$ & $\begin{array}{l}\text { Maximum and } \\
\text { minimum }\end{array}$ \\
\hline \multirow{4}{*}{ As an office tool (V1) } & $\mathrm{VF}$ & 2 & \multirow{4}{*}{2.65} & \multirow{4}{*}{0.77} & \multirow{4}{*}{$\begin{array}{l}\text { Max:4 } \\
\text { Min:1 }\end{array}$} \\
\hline & $\mathrm{F}$ & 12 & & & \\
\hline & Q & 16 & & & \\
\hline & $\mathrm{VM}$ & 4 & & & \\
\hline \multirow{4}{*}{$\begin{array}{l}\text { As support for the contents of the } \\
\text { subject through the expansion of } \\
\text { knowledge (V2) }\end{array}$} & VF & 0 & \multirow{4}{*}{3.29} & \multirow{4}{*}{0.67} & \multirow{4}{*}{$\begin{array}{l}\text { Max:4 } \\
\text { Min:2 }\end{array}$} \\
\hline & $\mathrm{F}$ & 4 & & & \\
\hline & Q & 16 & & & \\
\hline & $\mathrm{VM}$ & 14 & & & \\
\hline \multirow{4}{*}{ As a methodology for any topic (V3) } & $\mathrm{VF}$ & 2 & \multirow{4}{*}{2.59} & \multirow{4}{*}{0.78} & \multirow{4}{*}{$\begin{array}{l}\text { Max:4 } \\
\text { Min:1 }\end{array}$} \\
\hline & $\mathrm{F}$ & 14 & & & \\
\hline & Q & 14 & & & \\
\hline & VM & 4 & & & \\
\hline \multirow{4}{*}{$\begin{array}{l}\text { As collaborative work with other } \\
\text { colleagues to perform common tasks } \\
\text { (V4) }\end{array}$} & $\mathrm{VF}$ & 2 & \multirow{4}{*}{2.65} & \multirow{4}{*}{0.84} & \multirow{4}{*}{$\begin{array}{l}\text { Max:4 } \\
\text { Min:3 }\end{array}$} \\
\hline & $\mathrm{F}$ & 14 & & & \\
\hline & Q & 12 & & & \\
\hline & $\mathrm{VM}$ & 6 & & & \\
\hline \multirow{4}{*}{ To work autonomously (V5) } & $\mathrm{VF}$ & 0 & \multirow{4}{*}{3.06} & \multirow{4}{*}{0.64} & \multirow{4}{*}{$\begin{array}{l}\text { Max:4 } \\
\text { Min:2 }\end{array}$} \\
\hline & $\mathrm{F}$ & 6 & & & \\
\hline & Q & 20 & & & \\
\hline & VM & 8 & & & \\
\hline \multirow{4}{*}{$\begin{array}{l}\text { To develop digital teaching materials } \\
\text { such as webquest, edublogs and } \\
\text { videoclips (V6) }\end{array}$} & $\mathrm{VF}$ & 4 & & & \\
\hline & $\mathrm{F}$ & 18 & 241 & 092 & Max:4 \\
\hline & Q & 6 & 2.41 & 0.92 & Min:1 \\
\hline & VM & 6 & & & \\
\hline & VF & 0 & & & \\
\hline In sunport of texthooks (V7) & $\mathrm{F}$ & 2 & 220 & 0.57 & Max:4 \\
\hline In support of textbooks (v/) & Q & 20 & 3.29 & 0.51 & Min:2 \\
\hline & $\mathrm{VM}$ & 12 & & & \\
\hline & VF & 6 & & & \\
\hline To support the student's relationship & $\mathrm{F}$ & 14 & 235 & 0.91 & Max:4 \\
\hline with his/her family (V8) & Q & 10 & 2.35 & 0.91 & Min:1 \\
\hline & VM & 4 & & & \\
\hline & $\mathrm{VF}$ & 1 & & & \\
\hline As instruments to improve the learning & $\mathrm{F}$ & 12 & 230 & 087 & Max:4 \\
\hline of their students (V9) & Q & 10 & 2.30 & 0.81 & Min:2 \\
\hline & VM & 11 & & & \\
\hline & VF & 0 & & & \\
\hline As a social resource (V10) & $\mathrm{F}$ & 8 & 300 & 0.67 & Max:4 \\
\hline As a social resource (VIU) & Q & 10 & 3.00 & $0.0 \%$ & Min:2 \\
\hline & VM & 8 & & & \\
\hline & VF & 4 & & & \\
\hline To evaluate the knowledge and skills of & $\mathrm{F}$ & 12 & 065 & 0.98 & Max:4 \\
\hline the students (V11) & Q & 10 & 0.05 & 0.98 & Min:1 \\
\hline & VM & 8 & & & \\
\hline & VF & 6 & & & \\
\hline I ike a virtual cloicter (V12) & $\mathrm{F}$ & 10 & 253 & 099 & Max:4 \\
\hline Like a virtual cloister (V IL) & Q & 12 & 2.33 & 0.99 & Min:1 \\
\hline & VM & 6 & & & \\
\hline
\end{tabular}




\begin{tabular}{|c|c|c|c|c|c|}
\hline Ítem & Fre & ices & Means $(M)$ & $\begin{array}{c}\text { Standard } \\
\text { deviation }(S D)\end{array}$ & $\begin{array}{l}\text { Maximum and } \\
\text { minimum }\end{array}$ \\
\hline \multirow{4}{*}{ As a development of PLE (V13) } & VF & 10 & \multirow{4}{*}{2.12} & \multirow{4}{*}{0.91} & \multirow{4}{*}{$\begin{array}{l}\text { Max:4 } \\
\text { Min:1 }\end{array}$} \\
\hline & $\mathrm{F}$ & 12 & & & \\
\hline & $\mathrm{Q}$ & 10 & & & \\
\hline & $\mathrm{VM}$ & 2 & & & \\
\hline \multirow{4}{*}{ For continuing education (V14) } & VF & 2 & \multirow{4}{*}{2.53} & \multirow{4}{*}{0.78} & \multirow{4}{*}{$\begin{array}{l}\text { Max:4 } \\
\text { Min:1 }\end{array}$} \\
\hline & $\mathrm{F}$ & 16 & & & \\
\hline & Q & 12 & & & \\
\hline & VM & 4 & & & \\
\hline
\end{tabular}

Note: Very few (VF), Few (F), Quite (Q), Very much (VM)

Table 3. Dimension values linked to the use of ICT by teachers in their classroom

As can be seen in Figure 2, teachers - from the point of view of the coordinators - have not introduced ICTs convincingly in their profession.

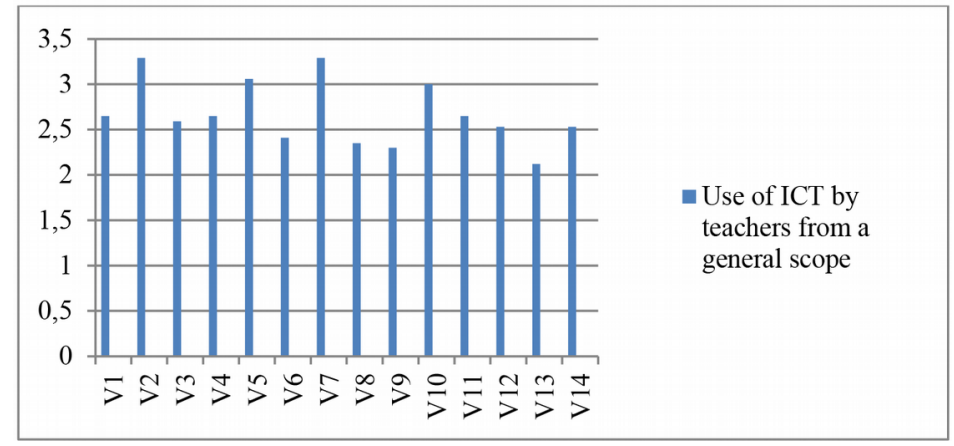

Figure 2. Means comparison

\subsection{Incidence of ICT in the Classroom}

From the more concrete point of view of teacher performance in the classroom, the results suggest that while knowledge increases with ICT-based content, it is not necessarily used to generate new content.

ICTs are not used mostly to generate new attitudes, nor to modify the teacher-student relationship, nor is there a relationship with other centres: they is not shared between schools, as can be seen in Table 4 .

\begin{tabular}{|c|c|c|c|c|c|}
\hline Ítem & \multicolumn{2}{|c|}{ Frequency } & Means $(M)$ & $\begin{array}{c}\text { Standard } \\
\text { Desviation }(S D)\end{array}$ & $\begin{array}{l}\text { Maximun and } \\
\text { minimum }\end{array}$ \\
\hline \multirow{4}{*}{ To clarify unfamiliar concepts (V1) } & VF & 2 & \multirow{4}{*}{2.41} & \multirow{4}{*}{0.78} & \multirow{4}{*}{$\begin{array}{l}\text { Max:4 } \\
\text { Min:1 }\end{array}$} \\
\hline & $\mathrm{F}$ & 20 & & & \\
\hline & Q & 8 & & & \\
\hline & VM & 4 & & & \\
\hline \multirow{4}{*}{$\begin{array}{l}\text { Promote new teacher-student } \\
\text { relationships (V2) }\end{array}$} & VF & 2 & \multirow{4}{*}{2.59} & \multirow{4}{*}{0.85} & \multirow{4}{*}{$\begin{array}{l}\text { Max:4 } \\
\text { Min:1 }\end{array}$} \\
\hline & $\mathrm{F}$ & 16 & & & \\
\hline & Q & 10 & & & \\
\hline & $\mathrm{VM}$ & 6 & & & \\
\hline \multirow{4}{*}{$\begin{array}{l}\text { To offer comments on their } \\
\text { performance (V3) }\end{array}$} & VF & 0 & \multirow{4}{*}{2.76} & \multirow{4}{*}{0.81} & \multirow{4}{*}{$\begin{array}{l}\text { Max:4 } \\
\text { Min:2 }\end{array}$} \\
\hline & $\mathrm{F}$ & 16 & & & \\
\hline & $\mathrm{Q}$ & 10 & & & \\
\hline & VM & 8 & & & \\
\hline \multirow{4}{*}{$\begin{array}{l}\text { To allow access to more information } \\
\text { (V4) }\end{array}$} & VF & 0 & \multirow{4}{*}{3.35} & \multirow{4}{*}{0.48} & \multirow{4}{*}{$\begin{array}{l}\text { Max:4 } \\
\text { Min:3 }\end{array}$} \\
\hline & $\mathrm{F}$ & 0 & & & \\
\hline & $\mathrm{Q}$ & 22 & & & \\
\hline & VM & 12 & & & \\
\hline
\end{tabular}




\begin{tabular}{|c|c|c|c|c|c|}
\hline Ítem & \multicolumn{2}{|c|}{ Frequency } & Means $(M)$ & $\begin{array}{c}\text { Standard } \\
\text { Desviation }(S D)\end{array}$ & $\begin{array}{l}\text { Maximun and } \\
\text { minimum }\end{array}$ \\
\hline \multirow{4}{*}{$\begin{array}{l}\text { As a facilitator of self-learning and } \\
\text { individualisation of teaching (V5) }\end{array}$} & VF & 0 & \multirow{4}{*}{3.18} & \multirow{4}{*}{0.80} & \multirow{4}{*}{$\begin{array}{l}\text { Max:4 } \\
\text { Min:2 }\end{array}$} \\
\hline & $\mathrm{F}$ & 8 & & & \\
\hline & Q & 12 & & & \\
\hline & VM & 14 & & & \\
\hline \multirow{4}{*}{$\begin{array}{l}\text { To facilitate the transfer of knowledge } \\
\text { (V6) }\end{array}$} & VF & 0 & \multirow{4}{*}{2.92} & \multirow{4}{*}{0.64} & \multirow{4}{*}{$\begin{array}{l}\text { Max:4 } \\
\text { Min:2 }\end{array}$} \\
\hline & $\mathrm{F}$ & 8 & & & \\
\hline & Q & 20 & & & \\
\hline & $\mathrm{VM}$ & 6 & & & \\
\hline \multirow{4}{*}{ To motivate students (V7) } & VF & 0 & \multirow{4}{*}{3.6} & \multirow{4}{*}{.50} & \multirow{4}{*}{$\begin{array}{l}\text { Max:4 } \\
\text { Min:3 }\end{array}$} \\
\hline & $\mathrm{F}$ & 0 & & & \\
\hline & Q & 14 & & & \\
\hline & VM & 20 & & & \\
\hline \multirow{4}{*}{ To facilitate group work (V8) } & VF & 0 & \multirow{4}{*}{2.94} & \multirow{4}{*}{0.81} & \multirow{4}{*}{$\begin{array}{l}\text { Max:4 } \\
\text { Min:2 }\end{array}$} \\
\hline & $\mathrm{F}$ & 12 & & & \\
\hline & Q & 12 & & & \\
\hline & $\mathrm{VM}$ & 10 & & & \\
\hline \multirow{4}{*}{$\begin{array}{l}\text { Presenting information with students } \\
\text { (V9) }\end{array}$} & VF & 0 & \multirow{4}{*}{3.41} & \multirow{4}{*}{0.60} & \multirow{4}{*}{$\begin{array}{l}\text { Max:4 } \\
\text { Min:2 }\end{array}$} \\
\hline & $\mathrm{F}$ & 2 & & & \\
\hline & Q & 16 & & & \\
\hline & VM & 16 & & & \\
\hline \multirow{4}{*}{$\begin{array}{l}\text { Facilitating the recovery of } \\
\text { information and reinforce the } \\
\text { contents (V10) }\end{array}$} & VF & 0 & \multirow{4}{*}{3.2} & \multirow{4}{*}{0.72} & \\
\hline & $\mathrm{F}$ & 6 & & & Max:4 \\
\hline & Q & 16 & & & Min:2 \\
\hline & $\mathrm{VM}$ & 12 & & & \\
\hline & VF & 0 & & & \\
\hline To create / modify student attitudes & $\mathrm{F}$ & 16 & 271 & 076 & Max:4 \\
\hline (V11) & Q & 12 & 2.11 & 0.10 & Min:2 \\
\hline & VM & 6 & & & \\
\hline & $\mathrm{VF}$ & 0 & & & \\
\hline Develop practical activities related to & $\mathrm{F}$ & 8 & 212 & 076 & Max:4 \\
\hline the contents (V12) & Q & 14 & 2.12 & 0.10 & Min:2 \\
\hline & VM & 12 & & & \\
\hline & VF & 0 & & & \\
\hline Demonstrating and simulating & $\mathrm{F}$ & 12 & 282 & 072 & Max:4 \\
\hline phenomena and experiences (V13) & Q & 16 & 2.02 & 0.12 & Min:2 \\
\hline & VM & 6 & & & \\
\hline & VF & 4 & & & \\
\hline Exchange of information with other & $\mathrm{F}$ & 20 & 253 & 093 & Max:4 \\
\hline educational centres (V14) & Q & 4 & & & Min:1 \\
\hline & VM & 6 & & & \\
\hline & VF & 4 & & & \\
\hline Establish innovation groups through & $\mathrm{F}$ & 20 & 235 & 092 & Max:4 \\
\hline virtual networks of centres (V15) & Q & 4 & 2.03 & 0.92 & Min:1 \\
\hline & VM & 6 & & & \\
\hline
\end{tabular}

Note: Very few (VF), Few (F), Quite (Q), Very much (VM)

Table 4. Dimension values linked to the use of ICT by teachers in their classroom 
It can be affirmed that an impulse is needed to be able to consider ICT as an alternative to the purely transmitting methodology in the classrooms since it reinforces the contents guarantees the transfer of information and also motivates the students.

\subsection{Organisational Strategies for the Application of ICT}

According to the data (Table 5), a new culture that is shared by all subjects is necessary, developing projects in a network. The coordinators are inclined to develop research in teacher training models, both initial and permanent.

\begin{tabular}{|c|c|c|c|c|c|}
\hline Ítem & \multicolumn{2}{|c|}{ Frequence } & Means (M) & \begin{tabular}{|c|} 
Standars \\
Desviation $(S D)$
\end{tabular} & $\begin{array}{l}\text { Maximun and } \\
\text { minimum }\end{array}$ \\
\hline \multirow{4}{*}{$\begin{array}{l}\text { A new network culture is necessary } \\
\text { (V1) }\end{array}$} & VF & 0 & \multirow{4}{*}{3.6} & \multirow{4}{*}{0.5} & \multirow{4}{*}{$\begin{array}{l}\text { Max:4 } \\
\text { Min:3 }\end{array}$} \\
\hline & $\mathrm{F}$ & 0 & & & \\
\hline & Q & 14 & & & \\
\hline & $\mathrm{VM}$ & 20 & & & \\
\hline \multirow{4}{*}{$\begin{array}{l}\text { Technology is integrated transversally } \\
\text { in the curriculum (V2) }\end{array}$} & VMF & 0 & \multirow{4}{*}{3.6} & \multirow{4}{*}{0.5} & \multirow{4}{*}{$\begin{array}{l}\text { Max:4 } \\
\text { Min:3 }\end{array}$} \\
\hline & $\mathrm{F}$ & 0 & & & \\
\hline & Q & 14 & & & \\
\hline & $\mathrm{VM}$ & 20 & & & \\
\hline \multirow{4}{*}{$\begin{array}{l}\text { There are subjects associated with } \\
\text { ICT learning instruments (V3) }\end{array}$} & VF & 6 & \multirow{4}{*}{2.47} & \multirow{4}{*}{1} & \multirow{4}{*}{$\begin{array}{l}\text { Max:4 } \\
\text { Min:1 }\end{array}$} \\
\hline & $\mathrm{F}$ & 12 & & & \\
\hline & Q & 10 & & & \\
\hline & $\mathrm{VM}$ & 6 & & & \\
\hline \multirow{4}{*}{$\begin{array}{l}\text { There is a need for a topic associated } \\
\text { with the methodological and didactic } \\
\text { use of ICT (V4) }\end{array}$} & $\mathrm{VF}$ & 6 & \multirow{4}{*}{2.76} & \multirow{4}{*}{1} & \multirow{4}{*}{$\begin{array}{l}\text { Max:4 } \\
\text { Min:1 }\end{array}$} \\
\hline & $\mathrm{F}$ & 6 & & & \\
\hline & Q & 12 & & & \\
\hline & $\mathrm{VM}$ & 10 & & & \\
\hline \multirow{4}{*}{$\begin{array}{l}\text { Technologies must be inserted } \\
\text { through complementary programs } \\
\text { (V5) }\end{array}$} & $\mathrm{VF}$ & 4 & \multirow{4}{*}{2.76} & \multirow{4}{*}{0.95} & \multirow{4}{*}{$\begin{array}{l}\text { Max:4 } \\
\text { Min:1 }\end{array}$} \\
\hline & $\mathrm{F}$ & 8 & & & \\
\hline & Q & 14 & & & \\
\hline & $\mathrm{VM}$ & 8 & & & \\
\hline \multirow{4}{*}{$\begin{array}{l}\text { It is necessary to develop research for } \\
\text { the development of models in initial } \\
\text { training (V6) }\end{array}$} & VF & 0 & \multirow{4}{*}{3.3} & \multirow{4}{*}{0.76} & \multirow{4}{*}{$\begin{array}{l}\text { Max:4 } \\
\text { Min:2 }\end{array}$} \\
\hline & $\mathrm{F}$ & 6 & & & \\
\hline & Q & 12 & & & \\
\hline & $\mathrm{VM}$ & 16 & & & \\
\hline \multirow{4}{*}{$\begin{array}{l}\text { Initial training should be developed in } \\
\text { b-learning models (V7) }\end{array}$} & $\mathrm{VF}$ & 0 & \multirow{4}{*}{3.5} & \multirow{4}{*}{0.7} & \\
\hline & $\mathrm{F}$ & 4 & & & Max:4 \\
\hline & Q & 10 & & & Min:2 \\
\hline & $\mathrm{VM}$ & 20 & & & \\
\hline & VF & 0 & & & \\
\hline The innovation and quality & $\mathrm{F}$ & 4 & & & Max:4 \\
\hline $\begin{array}{l}\text { department in the school is necessary } \\
\text { (V8) }\end{array}$ & Q & 16 & 3.3 & 0.67 & Min:2 \\
\hline & $\mathrm{VM}$ & 14 & & & \\
\hline & VF & 0 & & & \\
\hline The ICT coordinator must be part of & $\mathrm{F}$ & 0 & & & Max:4 \\
\hline $\begin{array}{l}\text { the innovation and quality department } \\
\text { (V9) }\end{array}$ & $\mathrm{Q}$ & 14 & 3.6 & 0.5 & Min:3 \\
\hline & $\mathrm{VM}$ & 20 & & & \\
\hline
\end{tabular}

Note: Very few (VF), Few (F), Quite (Q), Very much (VM)

Table 5. Dimension values linked to organisational strategies and the application of ICT 
In general, the coordinators see the need to work in the ICT of all subjects, it is not an isolated but transversal competence, in addition departments that deal with the advice and technological training of the teachers that the ICT coordinator should be in charge of should be promoted.

\subsection{Barriers that Prevent Further Implementation of ICT by the Teacher}

The most important barriers (Table 6) are due to the slowness with which changes in education and immobility in this profession occur. As expressed by the coordinators, and teachers in general, they need more hours to train and dedicate themselves to digital exchange with students. Nor do they see the relationship or complementarity between pedagogy and ICT and, therefore, do not insert it into their teaching work.

\begin{tabular}{|c|c|c|c|c|c|}
\hline Ítem & \multicolumn{2}{|c|}{ Frequency } & Means $(M)$ & $\begin{array}{c}\text { Standard } \\
\text { desviation }(S D)\end{array}$ & $\begin{array}{l}\text { Maximum and } \\
\text { minimum }\end{array}$ \\
\hline \multirow{4}{*}{$\begin{array}{l}\text { Lack of financial support, resources, } \\
\text { and management (V1) }\end{array}$} & VF & 8 & \multirow{4}{*}{2.59} & \multirow{4}{*}{1.1} & \multirow{4}{*}{$\begin{array}{l}\text { Max:4 } \\
\text { Min:1 }\end{array}$} \\
\hline & $\mathrm{F}$ & 6 & & & \\
\hline & Q & 12 & & & \\
\hline & VM & 8 & & & \\
\hline \multirow{4}{*}{$\begin{array}{l}\text { The slow process of teacher } \\
\text { appropriation to work in a more } \\
\text { integrated way with ICT (V2) }\end{array}$} & VF & 0 & \multirow{4}{*}{3.24} & \multirow{4}{*}{0.82} & \multirow{4}{*}{$\begin{array}{l}\text { Max:4 } \\
\text { Min:2 }\end{array}$} \\
\hline & $\mathrm{F}$ & 8 & & & \\
\hline & Q & 10 & & & \\
\hline & VM & 16 & & & \\
\hline \multirow{4}{*}{$\begin{array}{l}\text { Teachers did not include training } \\
\text { hours, materials, or digital exchange } \\
\text { with students in their workloads (V3) }\end{array}$} & VF & 4 & \multirow{4}{*}{2.65} & \multirow{4}{*}{0.84} & \multirow{4}{*}{$\begin{array}{l}\text { Max:4 } \\
\text { Min:1 }\end{array}$} \\
\hline & $\mathrm{F}$ & 8 & & & \\
\hline & Q & 18 & & & \\
\hline & VM & 4 & & & \\
\hline \multirow{4}{*}{$\begin{array}{l}\text { The amount of technological } \\
\text { resources in the classroom is not } \\
\text { proportional to the student and } \\
\text { academic population (V4) }\end{array}$} & $\mathrm{VF}$ & 4 & \multirow{4}{*}{2.35} & \multirow{4}{*}{0.84} & \multirow{4}{*}{$\begin{array}{l}\text { Max:4 } \\
\text { Min:1 }\end{array}$} \\
\hline & $\mathrm{F}$ & 18 & & & \\
\hline & Q & 8 & & & \\
\hline & $\mathrm{VM}$ & 4 & & & \\
\hline \multirow{4}{*}{$\begin{array}{l}\text { Little training of teachers in general to } \\
\text { apply ICT in their pedagogical } \\
\text { practices (V5) }\end{array}$} & VF & 0 & \multirow{4}{*}{3.3} & \multirow{4}{*}{0.76} & \multirow{4}{*}{$\begin{array}{l}\text { Max:4 } \\
\text { Min:2 }\end{array}$} \\
\hline & $\mathrm{F}$ & 6 & & & \\
\hline & Q & 12 & & & \\
\hline & VM & 16 & & & \\
\hline \multirow{4}{*}{ Lack of initial teacher training (V6) } & $\mathrm{VF}$ & 0 & \multirow{4}{*}{3.12} & \multirow{4}{*}{0.84} & \multirow{4}{*}{$\begin{array}{l}\text { Max:4 } \\
\text { Min:2 }\end{array}$} \\
\hline & $\mathrm{F}$ & 10 & & & \\
\hline & Q & 10 & & & \\
\hline & $\mathrm{VM}$ & 14 & & & \\
\hline \multirow{4}{*}{$\begin{array}{l}\text { The slow process of learning to use } \\
\text { ICT at a particular level (V7) }\end{array}$} & $\mathrm{VF}$ & 2 & \multirow{4}{*}{2.67} & \multirow{4}{*}{0.7} & \\
\hline & $\mathrm{F}$ & 10 & & & Max:4 \\
\hline & Q & 20 & & & Min:1 \\
\hline & $\mathrm{VM}$ & 2 & & & \\
\hline & VF & 2 & & & \\
\hline that prevent both teachers and & $\mathrm{F}$ & 16 & & & Max:4 \\
\hline students from having sufficient time & Q & 10 & 2.0 & 0.85 & Min:1 \\
\hline to insert ICT (V8) & VM & 6 & & & \\
\hline & VF & 2 & & & \\
\hline Institutional policies are not & $\mathrm{F}$ & 12 & & & Max:4 \\
\hline $\begin{array}{l}\text { sufficiently versed in or responsive to } \\
\text { ICT (V9) }\end{array}$ & Q & 16 & 2.65 & 0.77 & Min:1 \\
\hline & $\mathrm{VM}$ & 4 & & & \\
\hline
\end{tabular}




\begin{tabular}{|c|c|c|c|c|c|}
\hline Ítem & \multicolumn{2}{|c|}{ Frequency } & Means $(M)$ & $\begin{array}{c}\text { Standard } \\
\text { desviation }(S D)\end{array}$ & $\begin{array}{l}\text { Maximum and } \\
\text { minimum }\end{array}$ \\
\hline \multirow{4}{*}{$\begin{array}{l}\text { A full assessment of the participation } \\
\text { in ICT for each of the students is } \\
\text { missing (V10) }\end{array}$} & VF & 0 & \multirow{4}{*}{3.0} & \multirow{4}{*}{0.65} & \multirow{4}{*}{$\begin{array}{l}\text { Max:4 } \\
\text { Min: } 1\end{array}$} \\
\hline & $\mathrm{F}$ & 8 & & & \\
\hline & Q & 20 & & & \\
\hline & $\mathrm{VM}$ & 6 & & & \\
\hline \multirow{4}{*}{$\begin{array}{l}\text { The inability of teachers to change } \\
\text { (V11) }\end{array}$} & VF & 2 & \multirow{4}{*}{3.24} & \multirow{4}{*}{0.9} & \multirow{4}{*}{$\begin{array}{l}\text { Max:4 } \\
\text { Min:2 }\end{array}$} \\
\hline & $\mathrm{F}$ & 4 & & & \\
\hline & Q & 12 & & & \\
\hline & VM & 16 & & & \\
\hline \multirow{4}{*}{$\begin{array}{l}\text { The lack of collaborative work in the } \\
\text { centres (V12) }\end{array}$} & VF & 0 & \multirow{4}{*}{2.12} & \multirow{4}{*}{0.76} & \multirow{4}{*}{$\begin{array}{l}\text { Max:4 } \\
\text { Min:2 }\end{array}$} \\
\hline & $\mathrm{F}$ & 6 & & & \\
\hline & Q & 18 & & & \\
\hline & $\mathrm{VM}$ & 10 & & & \\
\hline \multirow{4}{*}{$\begin{array}{l}\text { The ICTs necessary for daily learning } \\
\text { are not yet considered (V13) }\end{array}$} & $\mathrm{VF}$ & 0 & \multirow{4}{*}{3.3} & \multirow{4}{*}{0.76} & \multirow{4}{*}{$\begin{array}{l}\text { Max:4 } \\
\text { Min:2 }\end{array}$} \\
\hline & $\mathrm{F}$ & 6 & & & \\
\hline & Q & 12 & & & \\
\hline & VM & 16 & & & \\
\hline
\end{tabular}

Note: Very few (VF), Few (F), Quite (Q), Very much (VM)

Table 6. Values of the dimensions linked to the barriers that ICTs have in classrooms

As more important barriers, the fact that the coordinators believe teachers do not know how to incorporate ICT in their pedagogical practices - and therefore do not consider it essential in their teaching, considering it superfluous or complementary - but not learning engine Teachers change their daily practice little or very little, although their personal life has undergone changes due to ICT.

\section{Discussion and Conclusion}

It is confirmed in the study that, in the opinion of the coordinators, teachers have made an effort to incorporate ICT into their teaching. It is known that there is another way to inform and transform information, but it does not generate knowledge by Yes, alone. The coordinators and the administration have done an admirable job, but their efforts appear insufficient, given that the teaching staff - since the proposals of Education 3.0 - have not advanced to a Teaching level of 4.0.

Our data confirm the results obtained in other international investigations (Haahr, Thomas, Nielsen, Hansen \& Jakobsen, 2005) and nationally (Area, 2005; Cabero-Almenara \& Alonso-García, 2007a,b; Cabero-Almenara \& Llorente-Cejudo, 2015). Also, the ICT coordinators in other regions such as Asturias (del Moral-Pérez, Villalustre \& Piñeiro, 2014), coincide with our conclusions. Teachers are aware that the modification of student learning through ICT is evident, and therefore requires ongoing training. They also know they do not yet have the desired impact on the classroom. Organisational strategies are necessary to promote greater development, since the fact of having more digital teaching material or computer equipment does not, in itself, imply a greater incidence in the classroom (and, therefore, a higher school performance; Marín-Vila, Carballo-Crespo \& Coloma-Carmona, 2018). In fact, the availability of computers could affect other skills, such as computer skills, but does not seem to be directly involved in improving academic performance. In our study, the fact that teachers - always from the opinion of the coordinators - did not see these tools as indispensable in their teaching work in the classroom, is significant. They also do not know how to use them such that their students can apply such learning to activities in, or interface with, society-at-large. The barriers that prevent it are the slow pace at which changes in education occur and, as well, teachers not recognising the educational possibilities ICTs offer in any subject or didactic proposal. Initial and ongoing training should receive proposals that support ICT from pedagogy, as many current studies (Fernández-Cruz, Fernández-Díaz \& Rodríguez-Mantilla, 2018; Moreno \& Piedra, 2018; Moreno \& Melo, 2018) - in all areas and in all competitions - have shown. 
The ICT coordinator must help, in the classroom, on the development of tasks or projects. One can immediately see how a complex series of knowledge and skills are intiated that allow research, reflection, modification, creation, and deriving a final product. This is where ICTs enter to facilitate and complete these processes. According to Burbano-González, Burbano-González, Márceles-Villalba, López-Pino \& Barría. (2017), planning the process and activities of informational, audiovisual, and digital literacy is an integrated and transversal task in the development of curricula in all areas. The multi-literacy process should not be planned as a separate action; regardless of the content and curricular objectives, they should be developed in the classroom (Europapress, 2016).

Limitations of our work involve the need to have contrasted the information derived with opinions of the teaching staff. However, this would entail another investigation. Our objective was to learn about the views of the ICT coordinators regarding the pedagogical panorama within the context in which they operate. Our ultimate objective was to encourage the development of ICT competence as a transversal to others. The study itself aims to verify a reality, thereby setting the stage to improve it. We sought to confirm, via the coordinators' opinion - that if the various centres and their teachers could benefit from ICT. Indeed, this curricular enhancement could serve as the engine of pedagogical change that is being needed. Thus, we offer the following as a supplement to previous proposals:

- Incorporate ICT in classrooms; computers/PCs should not be locked away in audiovisual or computer rooms (Area 2012), as is currently happening in many centres in Andalusia. since even being an ICT centre, students when they reach higher levels recognise their lack of training in This competition A few years ago, students were gifted with laptops; these have now disappeared from the life of the classrooms. Altogether, then, that investment has not served politically or pedagogically.

- Promote cooperative projects between teachers and students, both within a given centre and also with other centres. This should be done in a virtual way that promotes the current CEP in Andalusia, but in such that it draws from real-life situations and problems (Ley Orgánica 8/2013; Trujillo-Sáez, 2014).

- Question the monopoly of the textbook as a single source of knowledge and encourage students to seek new information through various sources and technologies (Area, 2018) as it has been found that this happens in the autonomous community of Andalusia (Rodríguez-Moreno, Pro-Bueno \& Molina-Jaén, 2018).

- Develop permanent training in accordance with the requirements required for ICT inclusion in classrooms of Andalusia (cf Molina-Jaén, Pérez-García \& Antiñolo-Piñar, 2012).

- In sum, it is proposed that the figure of the ICT coordinator be prominent in the educational environment and that his/her role be strengthened in the various centres. As part of that change, additional teacher training, as may be needed, should be provided.

\section{Declaration of Conflicting Interests}

The authors declared no potential conflicts of interest with respect to the research, authorship, and/or publication of this article.

\section{Funding}

The authors received no financial support for the research, authorship, and/or publication of this article.

\section{References}

Adell, J., \& Castañeda, L. (2012). Tecnologías emergentes, ¿pedagogías emergentes? In Hernández, J., Pennesi, M., Sobrino, D., \& Vázquez, A. (Coord.), Tendencias emergentes en educación con TIC (13-32). Barcelona: Asociación Espiral, Educación y Tecnología. 
Aigneren, M. (2005). El cuestionario. La Sociología en sus Escenarios, 11. Available at: https://aprendeenlinea.udea.edu.co/revistas/index.php/ceo/article/view/1696

Area, M. (2005). Las tecnologías de la información y comunicación en el sistema escolar. Una revisión de las líneas de investigación. Revista Electrónica de Investigación Y Evaluación Educativa, 11(1). Available at: https://www.uv.es/RELIEVE/v11n1/RELIEVEv11n1_1.htm https://doi.org/10.7203/relieve.11.1.4194

Area, M. (2012). Enseñar y Aprender con TIC: más allá de las viejas pedagogías. Aprender Para Educar Con Tecnología, 2, 4-7. Available at: https://issuu.com/programaeducadores/docs/aprenderparaeducar2

Area, M. (2018). Las aulas de la Escuel@Digit@1. Aula de innovación educativa, 269, 12-16.

Barroso-Osuna, J., \& Cabero-Almenara, J. (2013). Nuevos escenarios digitales. Las tecnologías de la información y la comunicación aplicadas a la formación y desarrollo curricular. Madrid: Ediciones Pirámide.

Best, J.W. (1972). Cómo investigar en educación. Madrid: Ediciones Morata.

Bisquerra-Alzina, R. (1989). Métodos de investigación educativa: guía práctica. Barcelona: CEAC.

Bringué-Sala, X., \& Sadaba-Chalezquer, C. (2009). Nacidos digitales: una generación frente a las pantallas. Navarra: RIALP.

Bringué, X., Sádaba, C., \& Tolsá, J. (2011). La generación interactiva en Iberoamérica 2010. Niños y adolescentes ante las pantallas. Madrid: Fundación Telefónica.

Burbano-González, D.C., Burbano-González, C.L., Márceles-Villalba, K., López-Pino, L.M., \& Barría, C. (2017). Alfabetización digital (AD) en las comunidades de aprendizaje bajo las mediaciones tecnológicas. IX Congreso Iberoamericano de Educación Cientifica y del I Seminario de Inclusión Educativa y Sociodigital (CIEDUC 2017) (1060-1077). Servicio de publicaciones.

Cabero-Almenara, J., \& Alonso-García, C.M. (2007a). Nuevas tecnologías aplicadas a la educación. Madrid: McGraw-Hill. https://doi.org/10.21556/edutec.1996.1.576

Cabero-Almenara, J., \& Alonso-García, C.M. (2007b). Tecnología educativa. Madrid: MacGraw-Hill. Available at: https://dialnet.unirioja.es/servlet/libro?codigo=12346

Cabero-Almenara, J., \& Llorente-Cejudo, M.C. (2015). Tecnologías de la Información y la Comunicación (TIC): escenarios formativos y teorías del aprendizaje. Revista Lasallista de Investigación, 12(2), 186-193. Available at: http://www.scielo.org.co/scielo.php?pid=S1794-44492015000200019\&script=sci abstract\&tlng=es https://doi.org/10.22507/rli.v12n2a19

Cantón-Mayo, I., Valle-Flórez, R.E., \& Arias-Gago, A.R. (2008). Calidad de la Docencia Universitaria: Procesos Claves. Educatio Siglo XXI, 26, 120-160. Available at: http://revistas.um.es/educatio/article/view/46651/

Carr, N. (2017). Superficiales: ¿Qué está haciendo Internet con nuestras mentes? Madrid: Taurus.

Christensen, C.M., Horn, M.B., \& Johnson, C.W. (2011). Disrupting class : how disruptive innovation will change the way the world learns. (2nd edition). Philadelphia: Bookhouse.

De Pablos-Pons, J., Bravo, P.C., \& Moreno, P.V. (2010). Políticas educativas, buenas prácticas y TIC. Education in the Knowledge Society (EKS), 11(1), 180-202.

Del Moral, M.E., Villalustre, L., \& Piñeiro, M.D. (2014). Oportunidades de las TIC para la innovación educativa en las escuelas rurales de Asturias. Aula Abierta, 42, 61-67. https://doi.org/10.1016/S02102773(14)70010-1 
Díaz, M.J.S., García, S.P., \& Muriel, D.D. (2010). Buenas prácticas organizativas para la integración de las TIC en el sistema educativo extremeño. Education in the Knowledge Society (EKS), 11(1), 148-179. Available at: https:// www.redalyc.org/articulo.oa?id $=201014897007$

Díaz-Sotero, P. (2012). Las cifras que demuestran el fracaso. La Educación en España. Sociedad. (January 29, 2018). El Mundo. Available at: http://www.elmundo.es/elmundo/2012/01/28/espana/1327772278.html

Donnelly, D., McGarr, O., \& O’Reilly, J. (2011). A framework for teachers' integration of ICT into their classroom practice. Computers \& Education, 57(2), 1469-1483.

https://doi.org/10.1016/j.compedu.2011.02.014

Europapress (2016) Los docentes reclaman formación en TIC y la introducción de proyectos digitales en el aula. (2016, 2 de julio). Europapress. Available at: http://www.europapress.es/portaltic/sector/noticiadocentes-reclaman-formacion-tic-introduccion-proyectos-digitales-aula-20160702132947.html

Fernández-Coca, A. (2012). Docencia 4.0. (January 25, 2012). El País. Available at: https://elpais.com/tecnologia/2012/06/08/actualidad/1339156111_565965.html

Fernández-Cruz, F.J., Fernández-Díaz, M.J., \& Rodríguez-Mantilla, J.M. (2018). El proceso de integración y uso pedagógico de las TIC en los centros educativos madrileños. Educación XX1, 21(2), 395-416. https://doi.org/10.5944/educxx1.17907

Formichella, M.M. (2018). TIC en la escuela y rendimiento educativo: el efecto mediador del uso de las TIC en el hogar. Cuaderno de Investigación Educativa, 9(1). https://doi.org/10.18861/cied.2018.9.1.2822

Fox, D. (1981). El proceso de investigación en educación. Pamplona: EUNSA.

González-Pérez, A. (2017). Dinamización tecnológica de la escuela a través del liderazgo del coordinador TIC. Estudios Pedagógicos (Valdivia), 43(2), 115-125. https://doi.org/10.4067/S0718-07052017000200006

Haahr, J.H., Thomas, C., Nielsen, K., Hansen, M.E., \& Jakobsen, S.T. (2005). Explicación del rendimiento escolar. Resultados de los estudios internacionales PISA, TIMSS y PIRLS. Available at: http://www.isei-ivei.net/cast/pub/rendimiento escolar.pdf

Hastamorir, M., Leandro, E., Castillo, P., \& Zuldemaida, D. (2019). Estrategia pedagógica mediada por las tic para la resolución de problemas asociados al concepto de número racional. Available at: http://repository.ucc.edu.co/handle/ucc/6485

Hernández, R.M., Cumpa, R.O., \& Rodríguez, S.Q. (2018). Nuevas formas de aprender: La formación docente frente al uso de las TIC. Propósitos y Representaciones, 6(2), 671-

701.https://doi.org/10.20511/pyr2018.v6n2.248

Ley Orgánica 8/2013, de 9 de diciembre, para la Mejora de la Calidad Educativa (LOMCE), Boletín Oficial del Estado (BOE ). 10 de diciembre de 2013. Available at: https://www.boe.es/buscar/act.php?id=BOE-A-2013-12886

Macià-Bordalba, M. (2016). La comunicación familia-escuela: el uso de las TIC en los centros de primaria. Revista Electrónica Interuniversitaria de Formación del Profesorado, 19(1), 73-83.

https://doi.org/10.6018/reifop.19.1.245841

Marín-Vila, M., Carballo-Crespo, J.L., \& Coloma-Carmona, A. (2018). Rendimiento académico y cognitivo en el uso problemático de Internet. Adicciones, 30(2), 101-110. https://doi.org/10.20882/adicciones.844

Mendoza, J., \& Garza, J.B. (2017). La medición en el proceso de investigación científica: Evaluación de validez de contenido y confiabilidad. Innovaciones de negocios, 6(1), 17-32. Available at: http://eprints.uanl.mx/12508/1/A2.pdf 
Monje-Fernández, A. (2012). Recursos educativos abiertos. Declaración de París. UNESCO. Available at: https://cedec.intef.es/recursos-educativos-abiertos-declaracion-de-paris-unesco/

Molina-Jaén, M.D., Pérez-García, P., \& Antiñolo-Piñar, J.L. (2012). Las TIC en la formación inicial y en la formación permanente del profesorado de infantil y primaria. Edutec. Revista Electrónica de Tecnología Educativa, 41, 211. https://doi.org/10.21556/edutec.2012.41.353

Moreno, E.L. \& Piedra, D.Z. (2018). Estrategia pedagógica mediada por las TIC para la resolución de problemas asociados al concepto de número racional (Trabajo de Fin de Maestría). Universidad Cooperativa de Colombia, Bogotá, Colombia.

Moreno, F.T.A., \& Melo, G.E.O. (2018). Una intervención pedagógica mediada por tic: Contribución para el mejoramiento del inglés en estudiantes de grado quinto. Didasc@, lia: Didáctica y Educación, 9(1), 189-210.

Ngoc-Thanh, T. (2019). Using ICT for ESL Learning at Primary Schools: Toward an Effective Implementation for Classroom Communication. In Khadimally, S. (Ed.), Technology-Assisted ESL Acquisition and Development for Nontraditional Learners. Pennsylvania, United States: IGI Global. https://doi.org/10.4018/978-1-5225-3223-1.ch002

Peláez, L.E., \& Osorio, B.E. (2015). Medición del nivel de aprendizaje con dos escenarios de formación: uno tradicional y otro con TIC. Entre Ciencia e Ingeniería, 9(18), 59-66. Available at: http://www.scielo.org.co/scielo.php?pid $=$ S1909-83672015000200008\&script $=$ sci abstract\&tlng $=\mathrm{es}$

Pérez-Juste, R. (2009). Estadística aplicada a la educación. Madrid: UNED.

Pisa Report (2009). Programa para la Evaluación internacional de alumnos. OCDE. Informe Español. Instituto de evaluación. Ministerio de Educación, Cultura y Deporte. Available at: http://iaqse.caib.es/documents/aval2009-10/pisa2009-informe-espanol.pdf

Pisa Report (2018). Marco de Competencia Global. Estudio PISA. Preparar a nuestros jóvenes para un mundo inclusivo y sostenible. Ministerios de Educación, Cultura y Deporte. Available at: http://www.educacionyfp.gob.es/inee/dam/jcr:df1f4128-5a8f-46f2-b0c4-498f3eb16698/PISA\%202018\%20Marco \%20Competencia $\% 20$ Global $\% 20$ (Digital).pdf

Prestridge, S. (2012). The beliefs behind the teacher that influences their ICT practices. Computers \& Education, 58(1), 449-458. https://doi.org/10.1016/j.compedu.2011.08.028

Ramos-Moreno, A.M., López-Fernández, V., \& Llamas-Salguero, F. (2017). Relación entre la creatividad, la memoria inmediata y lógica en relación al rendimiento académico Educación Secundaria. Revista Academia y Virtualidad, 10(1). https://doi.org/10.18359/ravi.2674

Reig, D. (2012). Doce cambios en el cerebro conectado (Message in a blog). Blog el Caparazón. Available at: http://www.dreig.eu/caparazon/2012/01/14/12-cambios-cerebro/

Rodríguez-Moreno, J., de Pro-Bueno, A., \& Molina-Jaén, M.D. (2018). Opinión de los docentes sobre el tratamiento de las competencias en los libros de texto de Ciencias de la Naturaleza en Educación Primaria. Revista Eureka sobre Enseñanza y Divulgación de las Ciencias, 15(3) 3102-3102. https://doi.org/10.25267/Rev_Eureka_ensen_divulg_cienc.2018.v15.i3.3102

Small, G. (2010). Internet mejora el cerebro. In Suarez, C. (Ed.), Sobre educación y virtualidad. Universidad de Salamanca. Available at: http://diarium.usal.es/csuarez/2010/01/04/internet-mejora-el-cerebro-entrevista-a-gary$\underline{\text { small/ }}$

Sosa-Diaz, M.J., \& Valverde-Berrocoso, J. (2017). Las macro-políticas educativas y el Proyecto de Educación Digital para la integración de las tecnologías desde la visión del profesorado. Revista de Educación a Distancia, 51, 1-28. https://doi.org/10.6018/red/51/3 
Sparrow, B., Liu, J., \& Wegner, D.M. (2011). Google effects on memory: Cognitive consequences of having information at our fingertips. Science, 333, 776-778. Available at: https://scholar.harvard.edu/dwegner/publications/google-effects-memory-cognitive-consequences-havinginformation-our-fingertips https://doi.org/10.1126/science.1207745

Suárez-Rodríguez, J., Almerich, G., Orellana, N., \& Díaz-García, I. (2018). A basic model of integration of ICT by teachers: competence and use. Educational Technology Research and Development, 66(5), 1165-1187. https://doi.org/10.1007/s11423-018-9591-0

Sutherland, R., Armstrong, V., Barnes, S., Brawn, R., Breeze, N., Gall, M. et al. (2004). Transforming teaching and learning: embedding ICT into everyday classroom practices. Journal of Computer Assisted Learning, 20(6), 413-425. https://doi.org/10.1111/j.1365-2729.2004.00104.x

Tondeur, J., van Keer, H., van Braak, J., \& Valcke, M. (2008). ICT integration in the classroom: Challenging the potential of a school policy. Computers \& Education, 51(1), 212-223.

https://doi.org/10.1016/j.compedu.2007.05.003

Trujillo-Sáez, F. (2014). Aprendizaje basado en proyectos: formación del profesorado de Educación Permanente. In Trujillo, F. (Blog). Available at: http://fernandotrujillo.es/aprendizaje-basado-en-proyectosformacion-delprofesorado-de-educacion-permanente/

Vera, J. (2016). Informe PISA: España sigue a la cola en Matemáticas y Ciencias aunque mejora en Lectura. El Español. Available at: https://www.elespanol.com/espana/sociedad/20161206/176232388 0.html

Wellington, J. (2001). Exploring the Secret Garden: the growing importance of ICT in the home. British Journal of Educational Technology, 32(2), 233-244. Available at: http://eprints.whiterose.ac.uk/502/ https://doi.org/10.1111/1467-8535.00193

Wishart, J. (2004). Internet safety in emerging educational contexts. Computers \& Education, 43(1-2), 193-204. https://doi.org/10.1016/j.compedu.2003.12.013

Published by OmniaScience (www.omniascience.com) Journal of Technology and Science Education, 2020 (www.jotse.org)

\section{(c) (i) (8)}

Article's contents are provided on an Attribution-Non Commercial 4.0 Creative commons International License. Readers are allowed to copy, distribute and communicate article's contents, provided the author's and JOTSE journal's names are included. It must not be used for commercial purposes. To see the complete licence contents, please visit https://creativecommons.org/licenses/by-nc/4.0/. 